Resenha recebida em:

05.03.2016

Aprovada em:

27.11.2016

Liliane de Lucena Ito

Doutoranda em Comunicação pela Unesp (Bauru,

SP). Mestra e jornalista pela mesma instituição. Bolsista Capes. E-mail: lilianedelucena@gmail. com

Estudos em Jornalismo e Mídia

Vol. 13 No 2

Julho a Dezembro de 2016

ISSNe 1984-6924

\title{
RESENHA: \\ É Preciso Pensar \\ a Crise do Jornalismo
}

Liliane de Lucena Ito

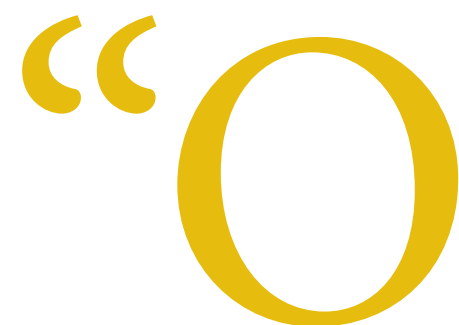

jornal im-

$\mathrm{p} \mathrm{resso}$ desaparecerá"; "vivemos um momento de democracia midiática"; "todos podem ser jornalistas com a web 2.0". Estas e outras tantas frases prontas buscam sintetizar cenários complexos sobre o futuro e o presente do jornalismo, numa tentativa apressada de oferecer respostas definitivas a questões que, apesar de urgentes, encontram-se em visível mutação. Fugir de prognósticos radicais é, no entanto, a proposta de Questões Para um Jornalismo em Crise (Editora Insular), publicado pelo Programa de Pós-Graduação em Jornalismo da Universidade Federal de Santa Catarina e organizado pelo professor Rogério Christofoletti, pesquisador referência no Brasil sobre crítica da mídia e ética jornalística.

Resultado das reflexões de 20 pesquisadores (que, em sua maioria, são também jornalistas) reunidos em disciplina ministrada por Christofoletti na pósgraduação, o livro traz discussões referentes à crise do jornalismo nos âmbitos da produção, distribuição, recepção e do modelo de negócio da atualidade e do futuro.

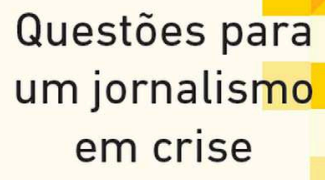

Rogério Christofoletti (org)

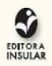

A abrangência do título é condizente à amplitude dos assuntos tratados. Ora sob o enfoque dos estudos de caso, ora abordando questões mais amplas e de caráter transversal, cada artigo oferece sua contribuição para a reflexão sobre a crise do jornalismo, seja ao discorrer sobre as variadas matrizes - o impresso, o televisado, o rádio, o digital - como também ao discutir elementos que tangenciam o tema, como a crítica da mídia e a paródia; as novas formas de se medir a audiência; a relação entre jornalismo e redes sociais; a execução da prática jornalística por amadores; o ensino da profissão mediante alterações curriculares em andamento no país e a reflexão fundamental sobre os limites e as prerrogativas da imprensa no que se refere à privacidade.

A obra é, assim, relevante e necessária por trazer discussões extremamente atuais: alguns de seus temas simplesmente não existiam - ou não eram discutidos - há apenas uma década. Tais discussões, mesmo que iniciais em alguns casos, alimentam reflexões inclusive sobre teorias clássicas do jornalismo (especialmente a Teoria do Gatekeeper e da Agenda Setting), uma vez que, na atualidade, a convergência midiática e cultural aliada às potencialidades da web 2.0 alteram significativamente relações de produção e 
recepção das notícias, possibilitando ao leitor um posicionamento ativo jamais visto até então.

Assinado pelas mestrandas Anna Russi e Magali Moser, e pelo doutorando Maurício Oliveira, $O$ que o futuro nos reserva? é o texto que abre o livro e funciona como uma introdução para as próximas páginas. Lembra-nos que, assim como ocorre agora com a internet, houve momentos em que a chegada de um novo meio provocou certa crise no jornalismo impresso. Com a grande diferença de que rádio e televisão mostraram-se, com o passar dos anos, complementares ao jornal, enquanto que a internet é um meio abrangente em si mesmo.

Em A Crítica de Mídia pode ajudar a superar a crise?, do mestrando Adriano Araújo, amplia-se o debate para a necessidade de regulamentação da mídia no Brasil, tema protelado por conta de claros interesses de partidos políticos e empresas que monopolizam os meios de comunicação e que, inevitavelmente, mantêm as amarras da imprensa. A temática também está presente em $A$ paródia do jornalismo contribui para sua crise representativa?, do mestrando Ricardo Sékula, uma vez que aqui são analisados elementos comunicacionais como memes, produzidos por pessoas comuns, anônimas, com a finalidade de apropriação e ressignificação paródica dos discursos oriundos da imprensa tradicional. O público, graças às ferramentas tecnológicas atuais, é capaz de revelar perspectivas ignoradas pela imprensa, além de tecer críticas ao perfil editorial dos veículos e ao despreparo do jornalista diante de determinadas situações.

O leitor pode estranhar a quantidade de perguntas ocupando o lugar de títulos, mas vale reiterar a proposta do livro: trazer questões que acendam o debate em torno de seus temas. Assim, Qual o papel das novas ferramentas na transformação do jornalismo?, dos mestrandos Kérley Winques e Ricardo Torres; Já temos uma alternativa para a reportagem multimídia?, do doutorando Alexandre Lenzi; Que novas possibilidades a segunda tela traz para a TV?, das mestrandas Mariane Ventura e Tássia Alexandre; É possível pensar um rádio esportivo pós-industrial?, de Jéssica Gonçalves, mestranda, e Dez anos depois, como estão os newsgames brasileiros?, de Ana Paula Bourscheid e Carlos Marciano, ambos mestrandos, são textos que oferecem pertinentes reflexões sobre a influência das novas tecnologias no produto jornalístico em si.

Tais artigos focam características, possibilidades e também limitações do jornalismo pensado para o patamar de consumo atual - em que o leitor passa a ser também usuário, pois aprecia formatos jornalísticos criativos que promovem a interação. Esse mesmo leitor-usuário informa-se por meio de elementos totalmente diferentes da notícia em seu padrão tradicional, seja via posts em redes sociais como também em newsgames. Soma-se a essas transformações no consumo - que influenciam os formatos oferecidos hoje - a questão da maneira como ocorre a leitura do material jornalístico, cada vez mais através de dispositivos móveis.

Mesmo extremamente relevante, ao ponto de centralizar o debate realizado nos cinco capítulos citados anteriormente, a tecnologia não é apresentada como único fator determinante para as transformações pelas quais o jornalismo passa na atualidade, erro de visão ainda comum entre alguns profissionais da área e que se reflete, por exemplo, na análise sobre a audiência de sites jornalísticos. A doutoranda Lívia Vieira sugere, em Vale tudo pelo clique?, que o atrelamento de decisões editoriais unicamente a métricas de acesso pode ser um grande erro na maneira de compreender os novos índices de consumo sobre o que é publicado on-line.

Já Como profissionais e amadores usam o Facebook para fazer jornalismo?, dos mestrandos Alexandre Bonacina e Mauren Rigo, resgata a recente trajetória dos veículos de imprensa em redes sociais no intuito de evidenciar transformações na linguagem e também alertar para riscos reais do jornalismo colaborativo.

O trabalho empírico Que imagem 
precária é essa que surge nos jornais?, do mestrando Vinicius de Oliveira, debruçase sobre a análise de imagens-flagrantes -amadoras, cada vez mais comuns desde o surgimento do primeiro aparelho de celular com câmera acoplada, em meados de 2000. Muito além do aspecto tecnológico, trata-se de um fenômeno social em que as pessoas estão acostumadas a vigiar e serem vigiadas 24 horas por dia, o que vai ao encontro das imagens flagrantes como "verdades" quase incontestáveis. O debate trazido por Rogério Christofoletti em Privacidade: o que podemos esperar quando não podemos mais esperar? articula-se à questão da vigilância, bem como ao monitoramento dos dados de cada indivíduo em ambientes em rede, problematizando as consequências ao negociar-se tão barato a privacidade, trocada muitas vezes em um clique que confere acesso a aplicativos gratuitos.

Como fica o ensino do jornalismo em meio às turbulências?, da doutoranda
Amanda Miranda e do mestrando Maurício Frighetto, aborda como futuros jornalistas estão sendo preparados para os novos desafios do mercado de trabalho, com vistas à aplicação das diretrizes curriculares propostas para os cursos de graduação em 2013.

Por fim, sem a pretensão de arriscar respostas definitivas, optando muitas vezes pelo caminho da experimentação, a obra serve como importante exercício de reflexão e atualização aos que se interessam pelas transformações atuais do jornalismo. Aos alunos de graduação, os textos tornam-se úteis por expor realidades e tendências que serão por eles experimentadas muito em breve. Aos investigadores acadêmicos, pontuam questionamentos aprofundados e trazem pesquisas e dados relevantes, ainda recentes sobre as diferentes mídias, públicos e empresas de comunicação, servindo como um interessante propulsor para novas reflexões. 